\title{
Congenital Hypothyroidism among Newborns and its Association with Maternal Biosocial Factors in Rajshahi Medical College Hospital
}

\author{
Md Shofiqul Islam, ${ }^{1}$ Md. Belal Hossain, ${ }^{2}$ Md Rustam Ali, ${ }^{3}$ \\ Md. Sanaul Haque Mia, ${ }^{4}$ Md. Belal Uddin, ${ }^{5}$ Md. Shameem ${ }^{6}$
}

\begin{abstract}
Congenital hypothyroidism is the commonest preventable cause of mental retardation. It is more prevalent in endemic goiter regions like Bangladesh. This study was done to assess the congenital hypothyroidism in neonates (age 4 to 28 days) admitted in Rajshahi Medical College Hospital. It was a cross sectional descriptive study conducted at pediatric department of Rajshahi Medical College Hospital from July 2016 to June 2018. After taking written consent from each mother/guardian, $3 \mathrm{ml}$ venous blood was collected and sent to the laboratory of Institute of Nuclear Medicine and Allied Sciences, Rajshahi to estimate serum TSH/ serum TSH and T4 level. Total $\mathbf{5 0 0}$ samples were collected in two years of study period. All information was put in the data collection sheet and was analyzed through standard statistical method by using SPSS version 16.0. Serum level of TSH $\geq 20 \mu \mathrm{lU} / \mathrm{ml}$ was considered as congenital hypothyroidism. Serum level increased but bellow $20 \mu \mathrm{IU} / \mathrm{ml}$ were recalled to repeat serum TSH level within 2 to 6 weeks of age. Among 500,321(64.2\%) male and 179 (35.8\%) female, Among 500 study population, 199 and 135 came from Rajshahi and Chapai Nawabganj district respectively. Total 7 mothers were hypothyroid and on thyroid replacement therapy. TSH level above 20 $\mu \mathrm{IU} / \mathrm{ml}$ was found in 5 neonates, 11 to $20 \mu \mathrm{IU} / \mathrm{ml}$ in 7 neonates. After repeat TSH testing one infant had serum TSH level above $20 \mu \mathrm{lU} / \mathrm{ml}$. Finally total 6 infants were diagnosed as having congenital hypothyroidism. Thus frequency of congenital hypothyroidism was $1.2 \%$. Congenital hypothyroidism in Rajshahi region is very high in relation to global incidence. Although this is not the actual picture of our country but this figure is alarming. Therefore neonatal screening program should be started as soon as possible to reduce the number of mentally retarded child. Maternal obesity and thyroidal status have significant association with neonatal TSH level.
\end{abstract}

Keywords: Congenital hypothyroidism, neonates, biosocial factors

TAJ 2019; 32: No-2: 36-42

\section{Introduction}

Congenital hypothyroidism is defined as thyroid hormone deficiency or defective thyroid function at birth. ${ }^{1}$ It is the most common congenital metabolic disorder seen in the newborn. Its prevalence showing marked geographical and racial variation. In developed countries, overall incidence is ranges from 1 in 3000 to 1 in 4000 newborn infants. ${ }^{2}$ But in India incidence is very high 1 in 1700 to 1 in $248 .^{3}$ The common type of $\mathrm{CH}$ is sporadic (85\%) and $15 \%$ are hereditary. Congenital hypothyroidism is more common in

1 Junior consultant (Paediatrics), Manda Upazilla Health Complex, Naogaon.

2 Junior consultant (Paediatrics), Rajshahi Medical College Hospital, Rajshahi.

${ }^{3}$ Resistrar, (Paediatrics), Rajshahi Medical College Hospital, Rajshahi.

${ }^{4}$ Professor and Head, Department of Paediatrics, Rajshahi Medical College, Rajshahi (Ex).

5 Professor and Head, Department of Paediatrics, Rajshahi Medical College, Rajshahi.

${ }^{6}$ Assistant Professor (Neonatology) Department of Paediatrics, Rajshahi Medical College, Rajshahi. 
Down syndrome (1:140). Prior to the onset of newborn screening programs the incidence as diagnosed after clinical manifestation was in the range 1 in 7000 to 1 in $10000 .^{4}$ It causes irreversible mental and physical disability if remains undetected. Diagnosis and treatment of $\mathrm{CH}$ is mandatory before 3 months of age to avoid cretinism. $^{5}$

Before the advent of screening in the 1970s, one third of children with $\mathrm{CH}$ were not detected until their $3^{\text {rd }}$ month of age, when they had already developed irreversible mental retardation. ${ }^{6}$ Iodine deficiency is the most important and easily preventable cause of mental retardation. Globally about $10 \%$ populations are suffering from iodine deficiency disorder and lack of iodine in mother leads to 30,000 still births and 120,000 $\mathrm{CH}^{7}$ Bangladesh is known to be one hyper endemic zone for iodine deficiency. Goiter and other iodine deficiency disorders are very common in our country. ${ }^{8}$ National survey for iodine deficiency disease in 1993 showed that the incidence of cretinism in our country is $0.5 \%$. But it was thought that the incidence would be much higher and one small study done at Institute of Nuclear Medicine, Dhaka shows that the prevalence rate of $\mathrm{CH}$ in Bangladesh is as high as $0.9 \%$ which is a cause of concern for physicians. ${ }^{9}$ In Bangladesh there is few institute based report on thyroid disorder. In recent community based study in southern part of Bangladesh it was revealed that $3.3 \%$ of school going children are suffering from thyroid insufficiency including hypothyroidism and sub-clinical hypothyroidism. ${ }^{10}$ Neonatal screening program for $\mathrm{CH}$ is highly cost effective for a nation because it prevents mentally retarded person. ${ }^{11}$ Therefore screening program has become a routine practice in all developed countries and many developing countries in South East Asia have inducted neonatal screening for $\mathrm{CH}$ as an essential part of their health services. ${ }^{12}$ In many countries it is done along with screening of other inborn errors of metabolism like phenylketonuria, tyrosinemia, maple syrup urine disease. Though Bangladesh situated in an iodine deficient area in the belt of Brahmaputra, no study is done on thyroid status in national level. Northern part of Bangladesh including Rajshahi region is more prevalence of hypothyroidism but no documented study on thyroid status of newborn in this region

The objective of this study was to evaluate the situation of $\mathrm{CH}$ in Rajshahi region rationalize the importance of neonatal screening program in this region.

\section{Materials and Methods}

This study was hospital based a cross-sectional descriptive one and conducted at the department of pediatrics in Rajshahi Medical College Hospital. Sampling criteria was purposive sampling. Study period was 2 years from July 2016 to June 2018. All neonates age 4 to 28 days admitted in paediatric wards who are not clinically sick were included in this study.

\section{Data collection procedure}

Patients were selected on the basis of inclusion and exclusion criteria. After taking written consent from parents/guardians, detail history was taken and proper physical examination was done. All information including history and examination findings were recorded in a predesigned clinical format in order to detect predisposing factors in relation to hypothyroidism. With all aseptic precautions $3 \mathrm{ml}$ venous blood was collected in a test tube and sent to the laboratory of Institute of Nuclear Medicine and Allied Sciences, Rajshahi. Then serum was separated and serum TSH/ serum TSH and serum T4 were assessed by RIA and IRMA methods.

\section{Results}

During 2 years study period, $3 \mathrm{ml}$ venous blood was collected from 500 newborns. Among them 321(64.2\%) male and 179 (35.8\%) female, 396(79.8\%) term and 104(20.8\%) were preterm. Most of babies (57.4) were age 4 to 7 days. Majority of babies came from Rajshahi (39.7\%) and Chapai Nawabganj (27\%) district. Other districts include Natore 9\%, Pabna 8.4\%, Naogaon 6.4\%, Kustia 6.4\%, Meherpur 2\% and Chuadanga 1\%. Most of mother came from lower socioeconomic class (42.4). 
Common age group of mothers was 21 to 25 years (37.4\%). Among 500, 9 mothers were obese and 7 mothers were hypothyroid and on thyroid replacement therapy. Most of mothers (85\%) were house wife. 352(70.4\%) mothers use iodized salt in cooking purpose. Most of mothers (80.4) came from rural areas. Serum TSH and serum T4 both were divided into 4 categories. Serum level of TSH >20 $\mu \mathrm{IU} / \mathrm{ml}$ consider as congenital hypothyroidism and should start treatment even normal total T4 and FT4 level. ${ }^{13}$ Higher levels of TSH were found in 5 neonates $(>20 \mu \mathrm{IU} / \mathrm{ml})$ which consider as congenital hypothyroidism (Table 1). Serum levels increased but bellow $20 \mu \mathrm{IU} / \mathrm{ml}$ were recalled for retesting. One neonate found $>20 \mu \mathrm{IU} / \mathrm{ml}$ after retesting when he was 35 days old. So, finally 6 infants were diagnosed as congenital hypothyroidism. Thus frequency of $\mathrm{CH}$ is $1.2 \%$. This is comparable to figure from rural areas of southern India. ${ }^{14}$ Mean serum TSH level was $3.08 \mu \mathrm{IU} / \mathrm{ml}$ in term and $2.96 \mu \mathrm{IU} / \mathrm{ml}$ in preterm babies. Serum T4 level was done in 470 neonates. 19 neonates were found very low $(\leq 39 \mathrm{nmol} / \mathrm{L})$ and 55 neonates were found low level than normal (Table 2). So, 74 neonates had low $(\leq 77.5 \mathrm{nmol} / \mathrm{L})$ level of serum T4 than normal. Among 74 neonates 3 were already diagnosed as congenital hypothyroidism on the basis of high serum TSH level. 71 neonates were recalled for follow up testing. 21 neonates did not come in follow up. 50 neonates were excluded for congenital hypothyroidism by follow up testing of serum TSH and serum FT4 levels. Mean serum T4 level was $113.91 \mathrm{nmol} / \mathrm{L}$ in term and $112.05 \mathrm{nmol} / \mathrm{L}$ in preterm babies. In this study serum TSH level was more sensitive than serum T4 level.

Table 1: Serum level of TSH among the study population $(n=500)$

$\begin{array}{ccc}\begin{array}{c}\text { TSH level } \\ \text { ( } \boldsymbol{\mu I U} / \mathbf{m l}\end{array} & \begin{array}{c}\text { No of } \\ \text { babies }\end{array} & \text { Percentage } \\ \text { Up to } 5 & 453 & 90.6 \% \\ 5.1-10 & 35 & 07 \% \\ 11-20 & 07 & 1.4 \% \\ >20 & 05 & 01 \% \\ \text { Total } & 500 & 100 \%\end{array}$

Table 2: Serum level of T4

$\begin{array}{ccc}\begin{array}{c}\text { Serum T4 } \\ \text { level (nmol/L) }\end{array} & \begin{array}{c}\text { No of } \\ \text { babies }\end{array} & \text { Percentage } \\ \text { Up to } 39 & 19 & 4.0 \% \\ 40-77.5 & 55 & 11.5 \% \\ 77.6-206 & 390 & 83 \% \\ >206 & 6 & 1.3 \% \\ \text { Total } & 470 & 100 \%\end{array}$


Table 3: Relation between neonatal serum TSH level and maternal BMI

$\begin{array}{llllll}\text { Maternal BMI } & \text { Number } & \begin{array}{l}\text { Mean } \\ (\boldsymbol{\mu I U} / \mathbf{m l})\end{array} & \text { TSH } & \text { Std. deviation } & \text { p Value } \\ <18.5 \text { (Under wt) } & 45 & 2.79 & 2.76 & \\ \text { 18.5-24.9 (normal) } & 339 & 2.69 & 4.44 & 0.045 \\ \text { 25-30(Over Wt) } & 107 & 3.18 & 6.67 & \\ >30 \text { (Obese) } & 09 & 6.37 & 11.16 & \\ \text { Total } & 500 & 3.00 & 5.09 & \end{array}$

Table 4: Characteristic features of hypothyroid babies

\begin{tabular}{|c|c|c|c|c|}
\hline Age district & $\mathbf{C} / \mathbf{F}$ & Clinical Dx & Investgation & $\begin{array}{c}\text { Age, occupation and } \\
\text { type of salt } \\
\text { consumption by } \\
\text { mother }\end{array}$ \\
\hline 19d, Rajshahi & $\begin{array}{l}\text { Feeding difficulty, } \\
\text { Res. distress }\end{array}$ & $\begin{array}{l}\text { Bronchopneumo } \\
\text { nia with } \\
\text { laryngomalacia }\end{array}$ & $\begin{array}{c}\text { TSH- } \\
42.22 \mu \mathrm{IU} / \mathrm{ml}, \\
\text { T4-52.83nmol/L }\end{array}$ & $\begin{array}{l}\text { 22y, House wife } \\
(\mathrm{HW}), \\
\text { Non iodized salt }\end{array}$ \\
\hline 22d, Nawabganj & $\begin{array}{c}\text { Cough, Res. Distress, } \\
\text { constipation }\end{array}$ & N. sepsis & $\begin{array}{c}\text { TSH-56.13 } \\
\text { T4-18 }\end{array}$ & $\begin{array}{c}\text { 22y, NGO service } \\
\text { Iodized salt }\end{array}$ \\
\hline 17d, Nawab ganj & $\begin{array}{l}\text { Jaundice, } \\
\text { constipation }\end{array}$ & N. jaundice & TSH-35.42 & $\begin{array}{l}\text { 22y NGO service } \\
\text { Non iodized }\end{array}$ \\
\hline 15d, Rajshahi & IDM, constipation & IDM & $\begin{array}{c}\text { TSH-35.51 T4- } \\
131.21\end{array}$ & $\begin{array}{c}\text { 35y NGO service } \\
\text { Iodized salt }\end{array}$ \\
\hline 28 d, Nawabganj & $\begin{array}{l}\text { Constipation, } \\
\text { distended abdomen, } \\
\text { Dry skin, cough }\end{array}$ & $\begin{array}{l}\text { Bronchopneumo } \\
\text { nia with } \\
\text { aerophagia }\end{array}$ & $\begin{array}{l}\text { TSH-9.13,34.88 } \\
\text { T4-47.60,153.57 }\end{array}$ & $\begin{array}{c}\text { 24y, HW, } \\
\text { Non iodized salt }\end{array}$ \\
\hline 28d, Rajshahi & $\begin{array}{l}\text { Cough, distended } \\
\text { abdomen }\end{array}$ & Aerophagia & $\begin{array}{c}\text { TSH-60 } \\
\text { T4-18.62 }\end{array}$ & $\begin{array}{l}\text { 22y, HW, Non iodized } \\
\text { salt }\end{array}$ \\
\hline
\end{tabular}

Table 5: Maternal thyroidal status with neonatal serum TSH level

\begin{tabular}{|c|c|c|c|c|}
\hline $\begin{array}{l}\text { Thyroidal status } \\
\text { of mother }\end{array}$ & No of mother & $\begin{array}{l}\text { Mean TSH level } \\
(\mu \mathrm{IU} / \mathrm{ml})\end{array}$ & Std. deviation & p value \\
\hline Euthyroid & 493 & 2.90 & 4.89 & 0.001 \\
\hline Hypothyroid & 07 & 9.76 & 11.93 & \\
\hline
\end{tabular}


Table 6: Maternal age and serum TSH level

$\begin{array}{lllll}\text { Age (yrs) } & \text { No. of mothers } & \begin{array}{l}\text { Mean value of TSH } \\ (\mu \mathrm{IU} / \mathrm{ml})\end{array} & \text { Std deviation } & \text { p value } \\ \text { Up to } 20 & 165 & 2.57 & 2.49 & 0.164 \\ 21-25 & 187 & 3.46 & 7.23 & \\ 26-30 & 101 & 2.49 & 2.45 & \\ >30 & 47 & 3.85 & 5.64 & \\ \text { total } & 500 & 3.00 & 5.10 & \end{array}$

Table 7: Neonatal serum TSH level and maternal iodine intake

$\begin{array}{lllll}\text { Maternal food habit } & \text { No of mothers } & \text { Mean serum TSH } & \text { Std deviation } & \text { p value } \\ \text { Iodized salt } & 352 & 2.84 & 4.16 & 0.27 \\ \text { Non iodized } & 148 & 3.38 & 6.82 & \end{array}$

Table 8: Neonatal serum TSH level and residence

$\begin{array}{lllll}\text { Residenc } & \text { No of babies } & \text { Mean TSH }(\mu \mathrm{IU} / & \text { Std deviation } & \mathrm{p} \text { value } \\ \text { Rural } & 402 & 2.98 & 5.30 & 0.80 \\ \text { Urban } & 98 & 3.12 & 4.15 & \end{array}$

\section{Discussion}

Congenital hypothyroidism is the most common preventable cause of mental retardation. $\mathrm{CH}$ can cause mental retardation unless thyroid therapy is initiated within two weeks of birth. ${ }^{15}$ Global incidence of $\mathrm{CH} 1$ in 4000 . But in India incidence is very high 1 in 1700 and 1 in 248. One study held in rural centre in southern India, 3 cases of congenital hypothyroidism were found screening 430 term neonates. In Bangladesh there is no nationwide tudy on congenital hypothyroidism. One hospital based study in Khulna showed incidence of congenital hypothyroidism was 1.5 per thousand. ${ }^{16}$ Another hospital based study, Alam et al in 1995 found that the prevalence of hypothyroidism was $10.12 \%$. In this study, incidence of congenital hypothyroidism is $1.2 \%$. This result indicates marked racial and geographical variation in the prevalence of hypothyroidism and very high prevalence of $\mathrm{CH}$ in Bangladesh including Rajshahi region.

A cross sectional study was carried out in nuclear medicine center in Chittagong to detect prevalence of cretinism of in two rural areas of Bangladesh, one in endemic area and another in non-endemic area. Number of population in this study was 4509 and prevalence of cretinism was $27(0.9 \%)$ in endemic area and no cases was found in nonendemic area. But in this study we found, increased level of serum TSH in neonates whose mothers used to take non iodized salt in comparison to those whose mothers took iodized salt which was not statistically significant (Table7). A study in the rural area of southern India, cord blood TSH were significantly higher in babies of mother with hypothyroidism. ${ }^{14}$ One study in Turkey, showed higher neonatal TSH recall rate in infants of mother of thyroid problem. ${ }^{18}$ This study showed that neonatal serum TSH level were 
significantly higher in neonates of hypothyroid mother (Table-5). A retrospective study in the Northwest India found that advanced maternal age was more common in children with thyroid dysgenesis. ${ }^{19}$ A cross sectional study in New York, showed that cord blood levels of TSH, total T4, FT4 were not associated with maternal age. In this study we observed highest level of serum TSH in group of mothers over the age of 30 years which is not statistically significant (Table 6). One study in USA showed that neonatal FT4 increased with increasing maternal obesity, while neonatal TSH levels were slightly increased in the obese groups in compared with normal weight. ${ }^{20}$ This study revealed that maternal obesity significantly associated with neonatal serum TSH (Table-3). One study done in Nakhon Pathom Province, Thailand revealed that the family income were low, high levels of of neonatal $\mathrm{TSH}^{21}$ In this study, we found that neonatal serum TSH level was not significantly associated with maternal socioeconomic condition. A study held in northern China showed serum TSH level were higher in infants of rural settings than that those of urban settings. ${ }^{22}$ But in this study we observed high level of TSH in infants of urban settings than those of rural settings which is not statistically significant(Table-8). So, there was no significant association with maternal age, social status, education and iodine intake.

\section{Conclusion}

The incidence of congenital hypothyroidism in the northern part of Bangladesh including Rajshahi region is quite high and screening for $\mathrm{CH}$ should be started immediately. A nationwide survey program is recommended before initiating this screening program.

\section{References}

1. Klett M. Epidemiology of congenital hypothyroidism. Expert Clin Endocrinol Diab.1997; 105 (s 04):19-23.

2. Susan R. Rose, Rosalind S. Brown. Update of newborn screening and therapy for congenital hypothyroidism. Pediatrics 2006; 117; 2290-2303.

3. Desai MP, Colaco MP, Ajgaokar AR, Mahadik CV, Rege C, Shirodkar W, et al. Neonatal Screening for congenital hypothyroidism in a developing country: problems and strategies. Indian J Pediatr, 1987;54:571-581

4. Rastogi MV, LaFranchi SH. Congenital Hypothyroidism. Orphanet J Rare Dis. 2010;5:17

5. Fisher DA. Disorders of the thyroid in the newborn and infant.In: Sperling (editor). Pediatric Endocrinology. Philadelphia, WB saunders 1996; 51-3

6. Desult $\mathrm{JH}$. The anecdotal history of screening for congenital hypothyroidism. J Clin Endocrinol Metab. 1999;84:4332-4

7. American Academy of Pediatrics \& American Thyroid Association. Newborn screening for congenital hypothyroidism: recommended guidelines. Pediatrics 1993; 91:123

8. Institute of Nuclear Medicine. Proceedings of National seminar on congenital hypothyroidism. Dhaka. Atomic Energy centre 18 June 2000

9. Siddiq SK, Ahmed T, Hoque R, Yasmin S, Ahmed $F$, Hussain M. Spectrum of thyroid disorders observed in the Institute of Nuclear Medicine. Bang Med J 1992; 21:71-4

10. Mia SR, Rasul CH, Moslem F. Study report on thyroid on thyroid disorders in children, Khulna. Centre for Nuclear Medicine. 2003.

11. Heyerdahl S, Kase BF, Lie SO. Intellectual development in children with congenital hypothyroidism in relation to recommended thyroxin treatment. J Pediatr 1991; 118:850-7

12. Basin SK, Kumar P, Dubey KK, Comparison of urinary iodine excretion and goiter survey to determine the prevalence of lodine deficiency. Ind. Pediatrics 2001; 38:901-5

13. de Silva S, Atapattu N, Wijesuriya P. de Silva L, de Silva $\mathrm{R}$, Amarasena $\mathrm{S}$ and Waidyanatha $\mathrm{S}$. Guidelines on management of congenital hypothyroidism in Srilaka.J Child Health 2015; 44(2): 75-76

14. Raj S, Baburaj S, George J, Abraham B, Singh S. Cord Blood TSH Level Variation in Newborns Experience from A Rural Centre in Southern India. Journal of Clinical and Diagnostic Research. 2014; 8(7): 18-20.

15. Smith L. Updated AAP Guidelines on newborn screening and Therapy for Congenital Hypothyroidism. Am Fam Physician. 2007 Aug 1; 76:439-444.

16. Rasul $\mathrm{CH}$, Lucky $\mathrm{SN}$, Miah SR, Moslem F. Congenital Hypothyroidism in the Southern Bangladesh. TAJ 2008; 21(1): 18-22. 
17. Ozdemir H, Akman I, Coskun S, Demirel U, Turan $\mathrm{S}$, Bereket $\mathrm{A}$, Bilgen $\mathrm{H}$, and Ozek E. Maternal Thyroid dysfunction and Neonatal Thyroid Problems. Hidawi, International Journal of Endocrinology 2013; 9878843

18. Dayal D, Sindhuja L, Bhattacharya A, and Bharti B. Advanced maternal age in Indian children with thyroid dysgenesis. Clin Pediatr Endocrinol 2015; 24(2).59-62

19. Maike K Kahr, Kathleen M. Antony, Melanie DelBeccaro, Min Hu, Kjersti M. Aagaard and Melissa A. Suter. Increasing maternal obnesity is associated with alterations in both maternal and neonatal thyroid hormone levels. Clinical Endocrinology (2016) 84, 551-557.

20. Punpetch S, Hancharean $K$, Factors Ifluencing Neonatal Thyroid Stimulating Hormone Level in Nakhon Pathom Province, Thailand. Proceeding of the $2^{\text {nd }}$ ASEAN plus Three Graduate Research Congress, Bangkok.2014

21. Choudhury N and Gorman KS. Subclinical Prenatal lodine Deficiency Negatively Affects Infant Development in Northern China. Community and International Nutrition Research Communication.2003; 3162-65 